\author{
Marcelina Pietryga (D) \\ University of Silesia \\ marcelina.pietryga@us.edu.pl
}

\title{
The Use of Explicitation to Retain the Foreignness of Olga Tokarczuk's Flights
}

\section{Introduction}

The novel Flights holds a special place among works written by Olga Tokarczuk, due to the fact that it was awarded the Man Booker International Prize in 2018 . The prize was received collectively by the author and the translator, Jennifer Croft. The novel focuses on the topic of travelling and movement as the inevitable aim of human life. Tokarczuk describes the stories of particular characters, as well as her own experiences related to various journeys and personal life. Such features give the possibility to present not only Polish characters (although the Slavic background is of particular importance here) but also to emphasize the aspect of foreignness, crucial for travelling. It is worth noticing that foreignness has an unusual function due to the fact that is appears originally in the source text (ST). As various phenomena are presented in the language foreign to the characters, they are perceived as unknown or difficult to understand. In order to preserve their status also in the target text (TT), which is written in English (the language used by the characters in some situations), the translator applies different textual modifications. The solution which 
Croft frequently chooses in this context is either explicitation or implicitation, which is directly related to the individual point of view presented by the protagonists. Furthermore, the uniqueness of this situation could be observed on the basis of the fact that out of 74 examples derived from all the chapters of the novel in which the translator decides to employ her substantial authorial modifications, 23 examples constitute a response to the foreignness present in the ST [Pietryga 2020a]. ${ }^{1}$ It has been observed that in the case of 13 examples the translator managed to retain the foreign background through the usage of explicitation; implicitation was implemented 3 times, whereas in the remaining examples Croft decides either to use other modifications or not to emphasize the aspects of foreignness.

The aim of this article is to examine explicitation in the English translation of Flights as the measure of retaining foreignness. Additionally, the study analyses the coexisting phenomenon of implicitation. The study is based on the product-oriented manual analysis of the ST and TT with the presentation of the most representative examples derived from the whole novel, which illustrate the most common forms of explicitation and implicitation. Moreover, the article puts emphasis on the reasons for foreignness appearing in the ST, a co-related aspect of an individual perspective of the described characters, as well as the general possibility of retaining foreignness.

\section{The relation between explicitation and implicitation}

One of the subjects which attracts a particular interest among scholars nowadays is the phenomenon of explicitation, which is often understood as an example of candidate for the universal of translation [Halverson 2003; Mauranen and Kujamäki 2004; Gumul 2006, 2017, 2020; Kamienická 2007a]. However, one can also observe some problems in this field which are either related to the lack of consistency regarding various definitions or a complete lack of any definition of the phenomenon [Becher 2010; Gumul 2006, 2017; Murtisari 2016]. As Klaudy and Károly [2005: 13] point out in their work, also implicitation is not devoid of its own problems, because it is often treated as a secondary, less important topic.

\footnotetext{
1 The examples analysed in this study come from the material collected for the author's MA thesis [Pietryga 2020a]. Authorial measures introduced by the translator into the translation of Flights were wider studied in the unpublished MA thesis of the author.
} 
In order to show the relations and dependence existing between the two discussed terms, it is necessary to present their definitions first. Probably the most frequently cited definition of explicitation comes from the work by Vinay and Darbelnet [1958/1995: 342]: "making explicit in the target language what remains implicit in the source language". This definition is treated as a point of departure by Gumul [2006: 20; 2017: 21], Pym [2005: 30], and Murtisari [2016: 67]. Moreover, both Gumul [2006: 19-20; 2017 : 21] and Murtisari [2016: 67] point out that this was the description which began the extraordinary interest in this field. However, more elaborate explanations of explicitation and implicitation, which will be simultaneously adopted by the author of this study as definitions classifying the shifts into the bounds of the two discussed phenomena, were developed by Klaudy and Károly who describe the first term in the following way:

Explicitation takes place [...] when a SL unit with a more general meaning is replaced by a TL unit with a more specific meaning; when the meaning of a SL unit is distributed over several units in the TL; when new meaningful elements appear in the TL text; when one sentence in the ST is divided into two or several sentences in the TT; or, when SL phrases are extended or "raised" to clause level in the TT etc. [Klaudy and Károly 2005: 15].

As can be observed, not only does the cited passage deny the opinion presented by Becher [2010: 3], who claims that some definitions referring to the phenomenon of explicitation do not describe the actual process of its occurrence and focus only on the TT, but also Klaudy and Károly [2005: 15] enumerate the textual manifestations which could lead to explicitating behaviour: "lexical specification, lexical division, lexical addition, grammatical specification, grammatical elevation (raising), grammatical addition." 2

Discussing the term of implicitation, one could also observe some gradation of definitions, from general to more specific one. The general definition could be found in the study by Murtisari [2013: 315], as she claims that "[i]mplicitation, [...] is seen to consist of making what is explicit in the source language implicit in the target language". In this case, it could be stated that the abovementioned definition focuses solely on the final stage of the process of implicitation, corresponding to the point of view

2 Contemporary literature offers also more detailed classifications of explicitation behavior like Gumul [2017], Tang [2018], Kamienická [2007b] and Hopkinson [2007]. 
presented hereinabove by Becher [2010: 3]. However, once again a more detailed and elaborate definition was established by Klaudy and Károly, who explain it in the following way:

[i]implicitation occurs [...] when a SL unit with a specific meaning is replaced by a TL unit with a more general meaning; when translators combine the meanings of several SL words in one TL word; when meaningful lexical elements of the SL text are dropped in the TL text; when two or more sentences in the ST are cojoined into one sentence in the TT; or, when ST clauses are reduced to phrases in the TT, etc. [Klaudy and Károly 2005: 15].

Whereas considering particular elements constituting the phenomenon of implicitation, Klaudy and Károly [ibidem] enumerate six measures: "lexical generalization, lexical contraction, lexical omission, grammatical generalization, grammatical lowering (downgrading) and contraction, and grammatical omission."

The first aspect of the relation between the two discussed terms could be concluded on the basis of the two general definitions created by Vinay and Darbelnet [1958/1995: 342] and Murtisari [2013: 315]. As could be observed, these elements are to some extent interdependent and often used to mutually define each other, creating the so-called circular definitions. Quite similar interdependence could be found in the operational symmetry created by Klaudy [2012]; nevertheless, in this case the author does not focus on the definitions themselves but rather draws attention to the actual usage of both phenomena. In her work the researcher states that "operational symmetry occurs when explicitation in one direction is paralleled by implicitation in the opposite direction" [ibidem: 23]. Quite similar opinion could be also detected in the earlier studies by Baumgarten, Meyer and Özçetin [2008: 179] and Saldanha [2008: 21] who likewise perceive the presence of both these measures in the ST and its translation, but simultaneously they believe that the original text is often expressed in a less explicit form in comparison to the TT.

Nevertheless, Klaudy [2012: 22-23] additionally points out to a reverse situation, called the asymmetry hypothesis, when "explicitation and implicitation are not always symmetric operations, as translators, when they have a choice, prefer operations involving explicitation [...] and often fail to perform operations involving implicitation." As the author emphasizes, this theory was first described by herself [eadem 2001] and subsequently developed with other scholars. Therefore, most of researches point out that 
explicitation could not be assigned to relations between languages but it rather appears as an independent phenomenon and as primary in this field is considered the study by Blum-Kulka [1986; see also Gumul 2017; Pym 2005; Tang 2018; Data-Bukowska 2016]. According to Pym [2005: 30-31], Blum-Kulka [1986] in her Explicitation Hypothesis stated that "a translation will be more explicit than a corresponding non-translation, which may be either the ST or a parallel text in the target language."

Referring to the previous arguments, the aspects which motivate the translator to implement this textual modification could be of particular importance. A broad description of intentions leading to explicitation could be found in the work by Gumul [2020]. The scholar divides the motives into four main categories: these related to cognitive issues, sociolinguistics aspects, personal and learned features of translator's style of translation, as well as the ST itself, which permits the usage of such phenomenon [ibidem: 187-190]. In the first type Gumul [ibidem: 187], referring to Olohan and Baker [2000], suggests that the discussed shift would not appear as a conscious decision applied by the translator, but rather as an outcome of cognitive processing which takes place in his/her mind. On the contrary, the second category not only refers to the deliberate application of explicitation, but also is strictly directed to the new recipient of the text [Gumul 2020: 187-188]. Moreover, the author enumerates scholars like Pym [2005] or Murtisari [2013] as representatives of this trend. Additionally, Gumul [2020: 188-189] and Data-Bukowska [2016: 50] point out that the translator is frequently aware of some difficulties related to the $\mathrm{ST}$ comprehension and therefore, $\mathrm{s} / \mathrm{he}$ wants to help the reader to find the faithful interpretation of the text. Nevertheless, Pym [2005: 41] claims that the discussed shift could be the result of "minimizing risk; or they [translators] do not want to take risk in their own name." Additionally, Gumul [2020: 189] suggests that trends prevailing in translation studies have a particular influence on the translator's behaviour. It corresponds to the observation by Sadza [2008: 333] who emphasizes that explicitation is currently a textual modification frequently chosen by translators.

In this context, one could wonder whether foreign elements appearing in the text are one of the reasons for explicitation. However, at this point the difference between foreignness and foreignization should be clearly stated. According to Eberharter [2009: 104-105], foreignness may be naturally inscribed in the given text and often its presentation in the translation is directly related to the translator's concept. According to Lewicki [2002], 
cited in Dąmbska-Prokop [2016: 208], the main indicator of foreignness is either foreign lexis or various elements of foreign culture. On the other hand, foreignization could be described as one of the most common approaches to translation, introduced by Venuti [2001]. ${ }^{3}$ On the basis of the study by Sadza [2008], it could be observed that explicitation may serve perfectly well as a response to foreign elements. First of all, it allows to precisely depict the aspects of the source culture which the target reader is naturally not able to understand, especially if they appear literally in the TT. In this case, the translator could use various forms of explanations that present the problematic phenomenon more clearly in comparison to its original version [ibidem: 326-327]. However, as some form of a side effect, this textual modification could affect the functions of the text, emphasizing its informative rather than emotional character [ibidem: 330, 332]. Secondly, Eberharter [2009: 109] believes that although the decision to preserve some words in their source language may handicap the comprehension of the TT, in fact it may be the only way to convey the foreignness appearing in the ST faithfully.

Worth noticing is the fact that both scholars [Sadza 2008; Eberharter 2009] conduct their studies on texts written originally in Polish, including the multiplicity of elements that may be either unknown to the target audience or constitute foreignness also to the ST readers. Finally, Eberharter [2009: 105] believes that probably the most appropriate approach, in this case, is to allow the reader to perceive the foreignness in the same form as it happens among the source readers. Additionally, Dąmbska-Prokop [2016: 209] draws attention to the fact that the TT which is not devoid of the foreign aspects may be interesting and vivid.

\section{Explicitation and implicitation in the translation of Flights}

\subsection{Explicitation as a textual modification}

The most common form of retaining foreignness in the translation of Flights is the turn from the implicitly expressed ideas existing in the ST to explicitation applied in the TT (this shift constitutes more than $50 \%$ of operations introduced as a response to the foreignness in the ST). Nevertheless, it is worth mentioning the unique characteristic of the ST, which could highly influence the solutions applied by the translator. In this case,

\footnotetext{
3 The exact features of foreignization and other techniques and strategies of translation could be found in another study of the author [Pietryga 2020b: 291].
} 
the discussed measure is used in the situation when Tokarczuk presents the world from the point of view of the English-speaking person where foreignness appears as the consequence of travelling. It results not only in the implementation of English lexis but also increases the subjective feeling of foreignness of Polish words. This issue could be exemplified by the following passage: Nie wiedziała na przyktad, co to znaczy "osoba publiczna”, musiała to przemyśleć, teraz już chyba wie. Co to znaczy "namieszać w życiu”. Narobić bałaganu? Zaszkodzić sobie? [Tokarczuk 2007: 328-329]. The quoted sentences and the doubts presented in them are uttered by a Pole who spent the majority of her life on the other continent, speaking solely English and now, on the request of her friend, the woman visits Poland. Therefore, some lexical structures may cause problems in understanding in the speaker's native language. In the ST, terms that pose difficulty are emphasized with the usage of quotation marks. Consequently, the aspects which are unintelligible and foreign could be easily concluded from the context, what may be directly related to the implicit presentation of information.

As translation is presented in English, the language the main character uses for most of her life, the discussed passage may look even more natural. Nevertheless, the translator still has to solve the problematic issue of Polish words. In this case Croft implements the following translation: "She didn't know, for example, what osoba publiczna meant, she'd had to think about it, though then she'd figured out it must be 'public figure'. But what did he mean by 'messed up'? That he'd made a mess out of things? That he'd harmed himself?" [eadem 2018: 299]. In order to emphasize the foreignness of the Polish words the translator decides to preserve the unintelligible expression in the original language, simultaneously presenting its familiar English equivalent, creating some unusual situation when the lexis from the ST is applied also in the TT. Because of that, the process is directly pointed out to the reader, which leads to a more explicit presentation of the text. Additionally, it could be observed that through such modification, Croft manages to preserve the exact level of foreignness which exists in the ST, as none of the information was lost in the translation.

A similar type of shift is applied frequently as a response to Polish lexis which constitutes problems to the speaker, which could be additionally illustrated by the following example: "And now she tells me in English that she came here when she was seventeen, with her parents; here she shows off with the Polish word for "mummy" [ibidem: 332]. Although in 
this case the whole passage is presented in English, the translator managed to clearly divide the part of the message presented in the other language from the sentences uttered entirely in English, simultaneously preserving the strong impact of foreignness which appears in Polish. In the ST such situation could be easily deduced from the context, through the emphasis appears in the form of quotations marks: I opowiada już angielszczyzna, $\dot{z} e$ przyjechała tutaj, gdy miała siedemnaście lat, z rodzicami, i teraz popisuje się stowem "mamusia" [Tokarczuk 2007: 365]. Considering the characteristisc of the translation and its original version, it could be suggested that in this context explicitation means not only stylistic changes which improve the reception of the text but in fact it compensates information which could be easily lost in the translation.

One more type of explicitation refers to the usage of English lexis. The application of foreign, English words in the text written in Polish may result in the need for their additional emphasis to the readers. This situation could be exemplified by the following passage: Po chwili wyciaga zeszyt, tadny notes, ręcznie szyty, kupiony zapewne $w$ jednym z tych sklepów, w których drogo sprzedaje się tanie wyroby z Trzeciego Świata; na okładce $z$ recyklingowanego papieru widnieje czarny druk Traveller's Log Book [ibidem: 449]. In this case the English phrase is a brand name of the notebook. It could be observed that not only does the author give information about the place of its origin, but also the recipient can easily distinguish the foreign element. Due to the fact that the name contrasts with the Polish sentence, no additional information about the languages used in this quotation is required.

However, the distinction between languages may not be observable in the English translation, when both the brand name and the surrounding text will be written in the same language. Therefore, Croft decides to translate it as follows: "After a while he gets out a notebook, a nice one, hand-sewn, probably from one of those shops that charges a fortune for cheap thirdworld products; it says 'Traveler's Log Book' in English on the recycledpaper cover" [Tokarczuk 2018: 408]. As could be observed the translator decides to explicitly divide the text into two parts. This measure allows preserving some level of foreignness existing in the novel and directly emphasizes the foreign origin of the text. Additionally, this modification could not be equated with over-translation, as together with the shift of language to English the context of the situation disappears and; consequently, the 
reader is not able to understand the implicit message, which could have a direct, negative impact on the comprehension of the novel.

Analysing the discussed examples, it could be observed that they contradict the general rule of foreignization due to the fact that various elements are in fact originally foreign to the readers of the ST. Therefore, in this context the translator does not introduce any new information which does not exist in the Polish version of Flights, but her aim is to preserve the original level of foreignness introduced by Tokarczuk and understandable to ST readers. Additionally, it can be stated that in all of the quoted examples, Croft manages to retain the elements of foreignness appearing as the consequence of travelling.

\subsection{Implicitation as a textual modification}

The second type of shift which also could be observed in the translation of Flights is implicitation, where foreign elements explicitly described in the ST appear in their implicit version in the TT. This textual modification refers to the cases where the author either decides to present the story from the point of view of a foreign language speaker or to add various English words, what may lead to the rare situation of the explicitly coded ST.

The prime example of the described situation could be observed in the following quotation: God's Zone, tak mówili o wyspie jej mieszkańcy. Strefa Boga. Tu się przeprowadzit i tutaj zabrał ze soba całe piękno świata [eadem 2007: 311]. This sentence also comes from the chapter describing the story of a Pole, living for most of her life in one of English speaking countries, who makes a decision to visit her old friend in her home country. However, this time the author decides to present the name in English and subsequently explain its meaning in Polish. It is worth mentioning here that Tokarczuk presents the literal translation of the English proper name, which highlights the foreign element and simultaneously leads to the explicitness of the ST. Considering the intention of the author, such measure may be reasoned by the aim to present a clearly understandable text [Pietryga 2020a: 69].

In order to avoid over-translation Croft applies the implicit version of this text and decides to omit the additional explanation: "Godzone, that's what the island's inhabitants call it. It's where God came to settle down, bringing with him all the beauty in the world" [Tokarczuk 2018: 283]. As can been observed, any explanation of the island's name in English would 
not only constitute a mistake, but what is more important it would not serve as a measure of retaining foreignness [Pietryga 2020a: 69-70].

Another category of shifts leading to implicitation refers to the usage of lexis of English origin. Although such word is in this context uttered by the native speaker of Polish, one could observe an increased explicitness of the ST:

Hostelom powinno się wytoczyć sprawę o ageizm, o dyskryminację ze względu na wiek. Z jakichś powodów przyjmują na noclegi tylko młodych, same sobie ustalaja te granice wieku, ale można być pewnym, że czterdziestolatek nie przejdzie [Tokarczuk 2007: 66].

The quoted passage comes from one of the short chapters, where Tokarczuk describes her own thoughts related to her travels, history and the surrounding world. In this quotation the author decides to implement the word of English origin. However, due to the fact that the term ageism has also its definition in the Polish PWN dictionary, ${ }^{4}$ it could be suggested that nowadays it is a term often used in the Polish language, constituting its integral part and therefore it may be understood also in the implicit version. Nevertheless, probably in order to avoid any confusion among the ST readers, the author implements an additional explanation in the form of an elaborated translation of the English word, increasing its explicitness.

Analysing the translation of this passage, one should bear in mind that the problematic term will be used here in the original language. Therefore, the translator chooses a following translation: "Hostels ought to be sued for ageism: for some reason, they only offer accommodation to the young" [eadem 2018: 63]. It could be observed that Croft does not decide to incorporate any additional explanation of the exact features of ageism but rather she prefers to apply it implicitly. Probably the reason for that would be not only the lack of any lexical necessity of explicitation, because both the word and the text are presented in English, but also the intention to avoid over-translation. Such situation would probably take place in the discussed context, if the quoted sentence had been translated literally. What is more, the exact types of possible over-translation are discussed by Gumul [2017: 32], who referring to Hejwowski [2015] enumerates three measures:

4 The term "ageism" in Polish means nietolerancja wobec osób starszych. See “ageizm”, [in:] Stownik języka polskiego PWN, [online] https://sjp.pwn.pl/sjp/ageizm;5569300.html, visited 18 November 2020. 
"unjustified additions, double renditions, and superfluous explanations." In relation to this quotation, any attempt to explain the problematic term would probably result in superfluous explanations which may disrupt the message of the text and introduce redundant elements. Instead, one could find symmetry between explicitation existing in the ST and implicitation appearing in the TT.

Referring to the analysis of the examples discussed in this section, one could wonder to which extent the translator manages to retain their foreignness. Nevertheless, firstly we should answer a question if the preservation of foreign elements was possible in this context at all. In this case Kalaga [1997: 13] points out the issue of some blockade of translation, where it is not possible to exactly convey the picture created by the author because the intended effect is possible solely through the words of the target language. Therefore, it is impossible to translate it into this target language without losing the effect it provides. A similar situation could be found in both of the discussed examples where the preservation of foreignness together with its explicit character is not possible and would not introduce any element necessary for the comprehension of the novel, thus the translator has to implement the textual modification in the form of implicitation. It can be suggested that this shift appears quite naturally as the lexis foreign to the ST readers is simultaneously known to the target audience.

\section{Conclusions}

On the basis of the described examples one could observe a very unique character of explicitation in Flights, as its main aim is to preserve the aspect of foreignness crucial for the novel, which has been deliberately applied by Tokarczuk and could be easily distinguished in the ST. Such feature is directly related to the personal perspective of protagonists, who, while travelling, encounter various means of foreignness. As this phenomenon is the part of the message conveyed by the author, the aim of the translator is to retain it in the most faithful form. Nevertheless, the novel also contains examples where it was not possible to preserve foreignness explicitly stated in the ST. Moreover, any attempt of its transmission would probably cause some confusion among TT readers or would entail overtranslation. In these cases, the translator decides to apply implicitation; however, such measure does not impoverish the content of the novel, as the omitted information could be usually deduced from the context of the 
TT. Although in the described examples one could easily discern the symmetry of the applied measures, it could be suggested that the changes do not result from the differences between the systems of the language and its grammar, but rather from the mode of the application of both languages and their subjective perception by the main characters. Therefore, it could be suggested that the possible lack of the measures applied by the translator would derange not only the comprehension of the text but also the level of foreignness applied by the author and subsequently may lead to some misunderstandings. Such situation emphasizes the need for the applied modifications. Nevertheless, it is also worth emphasizing the fact that the text itself and the primary design of the author highly determine the possibility of using of explicitation and implicitation. On the basis of the analysis, it could be suggested that retaining foreignness of the ST could also complement the scope of motives leading to explicitation.

\section{References}

“ageizm”, [in:] Słownik języka polskiego PWN, [online] https://sjp.pwn.pl/sjp/ ageizm;5569300.html, visited 18 November 2020.

Baumgarten, N., Meyer, B., Özçetin, D. (2008), "Explicitness in translation and interpreting: A critical review and some empirical evidence (of an elusive concept)", Across Languages and Cultures. 9(2): 177-203, https://doi.org/10.1556/ Acr.9.2008.2.2.

Becher, V. (2010), "Abandoning the notion of "translation-inherent" explicitation: Against a dogma of translation studies", Across Languages and Cultures. 11(1): 1-28, https://doi.org/10.1556/Acr.11.2010.1.1.

Blum-Kulka, S. (1986), "Shifts of cohesion and coherence in translation", [in:] Juliane House, Shoshana Blum-Kulka, eds. Interlingual and Intercultural Communication, Narr, Tübingen, 17-35.

Data-Bukowska, E. (2016), Eksplicytacja w nieprofesjonalnym przekładzie szwedzko-polskim. Perspektywa kognitywna, Wydawnictwo Uniwersytetu Jagiellonskiego, Kraków.

Dąmbska-Prokop, U. (2016), "Język przekładu w oczach polskich przekładoznawców”, Pótrocznik Językoznawczy Tertium. Tertium Linguistic Journal. 1(1\&2): 201-214, https://doi.org/10.7592/Tertium2016.1.2.Dambska.

Eberharter, M. (2009), “Obcość w literaturze i obcość w przekładzie: na podstawie thumaczeń najnowszej literatury polskiej na niemiecki”, Między Oryginatem a Przektadem. 15: 103-113. 
Gumul, E. (2006), “Eksplicytacja a komunikatywność tekstu przekładu”, [in:] Piotr Fast, Wacław M. Osadnik, eds. Przektad jako komunikat, Wydawnictwo Naukowe "Śląsk", Katowice-Warszawa-Częstochowa, 19-37.

Gumul, E. (2017), Explicitation in Simultaneous Interpreting: A Study into Explicitating Behaviour of Trainee Interpreters, Wydawnictwo Uniwersytetu Śląskiego, Katowice.

Gumul, E. (2020), "Dlaczego tłumacz mówi więcej niż autor? O eksplicytacji w przekładzie", Rocznik Przekładoznawczy. Studia nad teoria, praktyka i dydaktyka przektadu. 15: 177-197.

Halverson, S. (2003), "The cognitive basis of translation universals", Target. International Journal of Translation Studies. 15(2): 197-241, https://doi. org/10.1075/target.15.2.02hal.

Hejwowski, K. (2015), Iluzja przekładu, Wydawnictwo Naukowe "Śląsk", Katowice.

Hopkinson, C. (2007), "Explicitation and implicitation of binary coherence relations in translation", [in:] Renáta Tomaškova, ed. Translatologica Ostraviensia II. Sbornik z conference Den s prekladem, Universitas Ostraviensis, Ostrava, 53-59.

Kalaga, W. (1997), "Komizm a przekładalność", [in:] Piotr Fast, ed. Komizm a przekład, Wydawnictwo Naukowe "Śląsk", Katowice, 9-18.

Kamienická, R. (2007a), "Defining explicitation in translation", Brno Studies in English. 33(1): 45-57.

Kamienická, R. (2007b), "Dreaming the original: original and translation as two different fictional worlds", [in:] Kamila Vrankova, Christopher Koy, eds. Dream, Imagination and Reality in Literature. South Bohemian Anglo-American Studies, První vydání, University of South Bohemia, České Budějovice, 15-21.

Klaudy, K. (2001), "The asymmetry hypothesis. Testing the asymmetric relationship between explicitations and implicitations". Paper presented at the Third International Congress of the European Society for Translation Studies "Claims, Changes and Challenges in Translation Studies", Copenhagen, August 30 and September 1, 2001.

Klaudy, K. (2012), "Linguistic and cultural asymmetry in translation from and into minor languages", [in:] Hannu Kemppanen, Marja Jänis, Alexandra Belikova, eds. Dommestication and Foreignisation in Translation Studies, Franke and Timme, Berlin, 33-49. 
Klaudy, K., Károly, K. (2005), "Implicitation in Translation: Empirical evidence for operational asymmetry in translation", Across Languages and Cultures. 6(1): 13-28, https://doi.org/10.1556/Acr.6.2005.1.2.

Lewicki, R. (2002), "Obcość w przekładzie a obcość w kulturze”, [in:] Roman Lewicki, ed. Przektad, język, kultura, Wydawnictwo UMCS, Lublin, 43-52.

Mauranen, A., Kujamäki, P. (2004), Translation Universals. Do They Exist?, John Benjamins, Amsterdam-Philadelphia, https://doi.org/10.1075/btl.48.

Murtisari, E. T. (2013), "A relevance-based framework for explicitation and implicitation in translation", Trans-kom. 6(2): 314-344.

Murtisari, E. T. (2016), "Explicitation in translation studies: The journey of an elusive concept", The International Journal for Translation and Interpreting Research. 8(2): 64-81, https://doi.org/10.12807/ti.108202.2016.a05.

Olohan, M., Baker M. (2000), "Reporting 'that' in translated English. Evidence for subconscious processes of explicitation?", Across Languages and Cultures. A Multidisciplinary Journal for Translation and Interpreting Studies. 1(2): 141-158, https://doi.org/10.1556/Acr.1.2000.2.1.

Pietryga, M. (2020a), Translator as an author (based on "Flights" by Olga Tokar$c z u k$ ), Uniwersytet Śląski, Katowice (unpublished MA thesis).

Pietryga, M. (2020b), “Tłumacz jako autor na podstawie wybranych fragmentów powieści Olgi Tokarczuk Bieguni”, Rocznik Przekładoznawczy. Studia nad teoria, praktyka i dydaktyka przektadu. 15: 287-305, https://doi.org/10.12775/ RP.2020.014.

Pym, A. (2005), "Explaining explicitation”, [in:] Krisztina Károly, Ágota Fóris, eds. New Trends in Translation Studies: In Honour of Kinga Klaudy, Akadémiai Kiadó, Budapest, 29-43.

Sadza, A. (2008), "Poznawcza rola przekładu w relacjach międzykulturowych. O obcości w angielskim przekładzie powieści Hanemann Stefana Chwina (w tłumaczeniu Philipa Boehma)", Źródła Humanistyki Europejskiej. 1: 321-335.

Saldanha, G. (2008). "Explicitation revisited: bringing the reader into the picture", Trans-kom. 1(1): 20-35.

Tang, F. (2018), Explicitation in Consecutive Interpreting, John Benjamins Publishing Company, Amsterdam-Philadelphia.

Tokarczuk, O. (2007), Bieguni, Wydawnictwo Literackie, Kraków.

Tokarczuk, O. (2018), Flights (trans. Jennifer Croft), Fitzcarraldo Editions, Croydon.

Venuti, L. (2001), "Strategies of translation", [in:] Mona Baker, ed. Routledge Encyclopedia of Translation Studies, Routledge, London-New York, 240-244. 
Vinay, P. J., Darbelnet, J. (1958/1995), Comparative Stylistics of French and English: A Methodology for Translation, John Benjamins, Amsterdam-Philadelphia, https://doi.org/10.1075/btl.11.

\begin{abstract}
This article discusses the topic of explicitation applied as a measure of retaining foreignness in the English translation of Flights. It has been observed that the main types of explicitation used in the analysed novel are either explanations of the context which may be lost in the English translation or presentation of both, the problematic Polish words and their English explanation. The analysis has confirmed that explicitation gives the possibly to preserve almost exact level of foreignness as in the case of the source text. The second shift analysed in this study is implicitation, applied in a situation when retaining foreignness was not possible. This phenomenon has been implemented as a response to information explicitly stated in the source text. However, this measure does not negatively influence the TT, but on the contrary, it helps to provide a consistent and understandable text.
\end{abstract}

Keywords: explicitation, implicitation, foreignness, Olga Tokarczuk, translation

\title{
STRESZCZENIE
}

\section{Zastosowanie eksplicytacji jako sposobu zachowania obcości w an- gielskim przekładzie Biegunów Olgi Tokarczuk}

W niniejszym artykule poruszono temat zastosowania eksplicytacji jako sposobu zachowania obcości w angielskim przekładzie Biegunów. Zaobserwować można, że eksplicytacja przejawia się głównie w formie objaśnień kontekstowych, których obcość może zostać zatracona podczas przekładu, a także poprzez zachowanie polskich nazw oraz uzupełnienie ich o odpowiedniki anglojęzyczne. Jak wykazała analiza, zastosowanie eksplicytacji w przekładzie umożliwia przedstawienie obcości w takim stopniu, w jakim jest ona widoczna w tekście źródłowym. Kolejną modyfikacją tekstową, którą można zaobserwować w angielskim przekładzie Biegunów, jest implicytacja. Rozwiązanie to zostało zastosowane w sytuacji, gdy zachowanie obcości nie było możliwe. W tym kontekście 
zjawisko to wiąże się z informacjami przedstawionymi eksplicytnie już w oryginale, najczęściej w odniesieniu do nomenklatury anglojęzycznej, którą autorka pragnęła dookreślić. Analiza materiału wykazała, że zastosowanie implicytacji nie wpływa negatywnie na przekaz powieści, ponieważ informacje w niej przedstawione są czytelnikowi znane oraz nie wymagają uszczegółowienia.

Słowa kluczowe: eksplicytacja, implicytacja, obcość, Olga Tokarczuk, przekład 